\title{
PEMETAAN PASANG SURUT DAN ARUS LAUT PULAU BATAM DAN PENGARUHNYA TERHADAP JALUR TRANSPORTASI ANTARPULAU
}

\author{
TIDAL AND CURRENT MAPPING OF BATAM ISLAND AND THEIR EFFECT ON THE INTER-ISLAND \\ TRANSPORTATION
}

\author{
Sudra Irawan \\ Program Studi Teknik Geomatika Kelautan, Politeknik Negeri Batam \\ Corresponding author e-mail: sudra@polibatam.ac.id
}

Received: March 3, 2016/Accepted: March 29, 2016

\begin{abstract}
The strategic geographical position of Batam Island makes sea transportation become a basic means connecting the islands of the Riau Islands, Riau, Kalimantan, even with neighboring Singapore and Malaysia. The development of coastal areas and the determination of the transportation ways needs tidal and ocean currents data. This study measures and analyzes the tidal type usingmeasuring signs and current patterns using Lagrangian method, then presented in the web form. Five research sites were selected by purposive sampling method with a measurement time of 24 hours in one hour intervals. The results showed that the type of tidal in Batam Island in general is semidiurnal tide. Tidal period an average of 12 hours and 24 minutes. Wave height of about 0.2 to 2.77 meters from the south to the northwest. Batam Island ocean current patterns ranging from $0.02 \mathrm{~m} / \mathrm{s}$ to $0.1 \mathrm{~m} / \mathrm{s}$ from north towards the northeast. Tidal and current survey is one of the conditions in developing inter-island transportation. The tidal and current is useful in design port building, determining the route of transport, port basin design and planning of the breakwater.
\end{abstract}

Keywords: current patterns, lagrangian, signs measure, tidal, transport route.

\section{ABSTRAK}

Posisi geografis Pulau Batam yang strategis membuat jalur transportasi laut merupakan sarana dasar menghubungkan antarpulau di Kepulauan Riau, Riau, Kalimantan, bahkan dengan negara tetangga Singapura dan Malaysia. Pengembangan wilayah pesisir dan penentuan jalur transportasi membutuhkan data pasang surut dan arus laut. Penelitian ini mengukur dan menganalisis tipe pasang surut dengan rambu ukur dan pola arus dengan metode metode Lagrangian, kemudian disajikan dalam bentuk web. Dipilih lima lokasi penelitian berdasarkan metode Purposive Sampling dengan waktu pengukuran 24 jam dalam interval satu jam. Hasil penelitian menunjukkan bahwa tipe pasang surut pulau Batam secara umum adalah pasang surut harian ganda (semidiurnal tide). Periode pasang surut rata-rata 12 jam 24 menit. Tinggi gelombang sekitar 0,2 sampai 2,77 meter dari arah selatan ke arah barat laut. Pola arus laut pulau Batam berkisar antara 0,02 m/s sampai 0,1 m/s dari arah utara ke arah timur laut. Survei pasang surut dan arus laut merupakan salah satu syarat dalam mengembangkan transportasi antarpulau. Pasang surut dan arus berguna dalam kegiatan perancangan bangunan pelabuhan, penentuan rute transportasi, perancangan kolam pelabuhan, dan perencanaan pemecah gelombang.

Kata kunci: jalur transportasi, lagrangian, pasang surut, pola arus, rambu ukur.

\section{PENDAHULUAN}

Pulau Batam memiliki wilayah pesisir dan lautan seluas $2.950 \mathrm{Km}^{2}$ atau $73,93 \%$ dari luas total $3.990 \mathrm{Km}^{2}$ (Coremap Kota Batam, 2007). Ditinjau dari segi ekonomi sumberdaya pesisir dan laut di Pulau Batam sangat potensial untuk dikembangkan dalam rangka peningkatan kesejahteraan masyarakat, seperti pembangunan pelabuhan untuk transportasi antar pulau, pembangunan objek pariwisata, pembangkit energi listrik dan sebagainya. Oleh karena itu, untuk mendukung 
ISSN: 1907-9931 (print), 2476-9991 (online)

pembangunan tersebut dibutuhkan suatu informasi berupa pasang surut, namun sampai saat ini informasi pasang surut di Pulau Batam berdasarkan data Badan Informasi Geospasial (BIG) hanya meliputi daerah Kabil dan Sekupang. Sedikitnya informasi tentang pasang surut yang ada menyulitkan dalam pengembangan dan pembangunan Pulau Batam yang berkelanjutan dalam kegiatan transportasi laut, kegiatan di pelabuhan, dan juga pembangunan di daerah pesisir pantai.

Pasang surut merupakan fenomena alam mengenai permukaan perairan seperti lautan, yang berubah-ubah secara periode tertentu dan ketinggiannya sesuai dengan perubahan posisi bulan dan matahari terhadap bumi menurut fungsi waktu (Sutirto dan Diarto, 2014). Pemilihan Pulau Batam sebagai daerah yang dianalisis dalam penelitian ini dikarenakan masih kurangnya informasi-informasi terkait tentang pasang surut dan arus laut. Parameter yang dihasilkan dapat digunakan untuk meramalkan tipe pasang surut selama beberapa tahun mendatang. Melihat betapa pentingnya peranan pasang surut dan arus laut, maka diperlukan suatu informasi terkait pasang surut tersebut yang ditampilkan dalam bentuk peta yang memberikan informasi mengenai tipe pasang surut, grafik pasang surut, dan variasi muka air laut di beberapa lokasi yang diteliti.

\section{MATERI DAN METODE}

\section{Lokasi dan Waktu Penelitian}

Penelitian ini dilakukan dari bulan Agustus s.d Desember 2015 di lima lokasi yang bisa menggambarkan secara keseluruhan pasang surut dan arus laut di Pulau Batam seperti pada Gambar 1 dan Tabel 1.

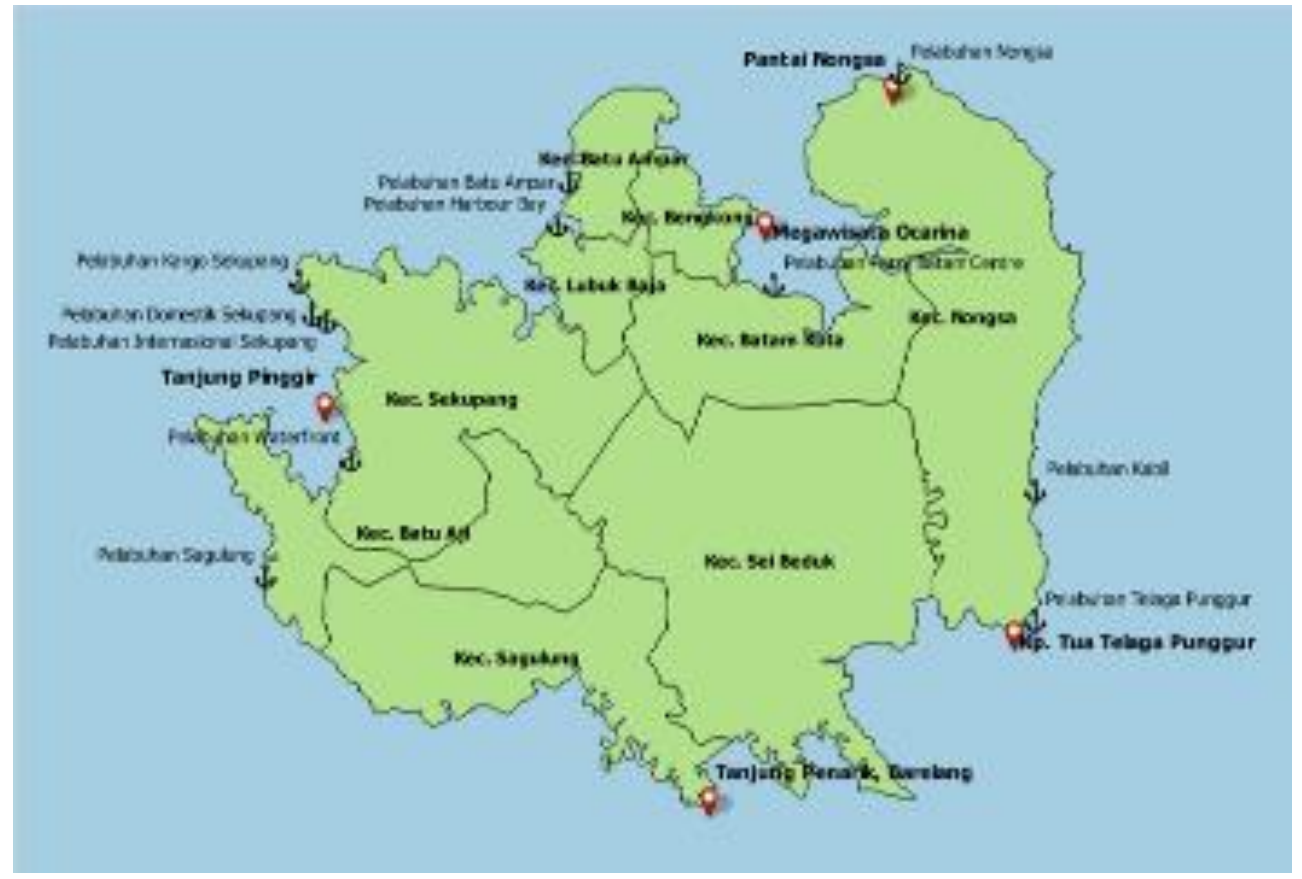

Gambar 1. Peta lokasi penelitian pasang surut dan arus laut di Pulau Batam 
ISSN: 1907-9931 (print), 2476-9991 (online)

Tabel 1. Lokasi penelitian pasang surut dan arus

\begin{tabular}{|c|c|c|c|}
\hline \multirow{2}{*}{ No } & \multirow{2}{*}{ Lokasi } & \multicolumn{2}{|c|}{ Koordinat } \\
\hline & & Lintang & Bujur \\
\hline 1 & Mega Wisata Ocarina & $01^{\circ} 9^{\prime} 11 "$ & $104^{\circ} 03^{\prime 2} 28^{\prime \prime}$ \\
\hline 2 & Pantai Nongsa & $01^{\circ} 11^{\prime} 36^{\prime \prime}$ & $104^{\circ} 05^{\prime} 43^{\prime \prime}$ \\
\hline 3 & $\begin{array}{l}\text { Pos Penjagaan Laut dan Pantai } \\
\text { (PLP) Tanjung Uban }\end{array}$ & $01^{\circ} 01^{\prime} 58^{\prime \prime}$ & $104^{\circ} 07^{\prime} 52^{\prime \prime}$ \\
\hline 4 & $\begin{array}{l}\text { POS Pangkalan TNI AL Tanjung } \\
\text { Riau }\end{array}$ & $01^{\circ} 06^{\prime} 00^{\prime \prime}$ & $103^{\circ} 55^{\prime} 41^{\prime \prime}$ \\
\hline 5 & $\begin{array}{l}\text { Tanjung Penarik Jembatan } 1 \\
\text { barelang }\end{array}$ & 059'02" & $104^{\circ} 02^{\prime 2} 29^{\prime \prime}$ \\
\hline
\end{tabular}

\section{Alat dan Bahan}

Alat dan bahan yang digunakan dalam penelitian ini disajikan pada Tabel 2.

Tabel 2. Alat dan bahan yang digunakan

\begin{tabular}{clll}
\hline No & Alat dan Bahan & \multicolumn{1}{c}{ Spesifikasi } & \multicolumn{1}{c}{ Fungsi } \\
\hline 1 & Bola Plastik & Mikasa & Untuk pengukuran \\
2 & Theodolit & TopCon & Pengukuran nilai \\
3 & Kompas & Kompas Geologi & Pengukuran arah \\
4 & GPS & GPS Handheld & Menentukan titik \\
5 & Rambu Ukur & Panjang 3 meter & Pengukuran pasang surut \\
6 & Stopwatc & HP & Menghitung waktu \\
7 & Tali & Tali Rapia & Penarik bola \\
8 & Plat Seng & Flamo & Penetuan arus \\
9 & Pemberat & Besi & Memberatkan bola \\
11 & Lem & Lem Setan & Pelekat bola \\
12 & Alat tulis & Pilot dan Standart & Mencatat semua data \\
\hline
\end{tabular}

\section{Desain Penelitian}

Desain penelitian pasang surut dan arus laut di Pulau Batam dijelaskan pada Gambar 2.

Penelitian ini dimulai dari survei rencana lokasi studi yang bertujuan untuk menentukan lokasi yang cocok untuk melakukan proses pengukuran. Tahap awal penentuan lokasi menggunakan peta yang dibuat melalui Quantum GIS 2.8.1, dengan lokasi utama difokuskan pada pelabuhan yang ada di Kota Batam. Setelah itu dilakukan pemilihan lokasi studi, berdasarkan survei rencana lokasi tersebut ditetapkan 5 lokasi pengukuran seperti disajikan dalam Tabel 1 dan Gambar 1. Pemilihan lokasi ini menggunakan metode Purposive Sampling, sampel diambil dengan maksud atau tujuan tertentu (Sudjana, 2015). Pada penelitian ini lokasi-lokasi yang dipilih bisa menggambarkan secara keseluruhan pasang surut di Pulau Batam. Tahap selanjutnya dilakukan pengukuran pasang surut dan arus laut. Setelah pengukuran selesai, maka dilakukan pengolahan data pasang surut yang memuat tiga aspek yaitu perhitungan muka air laut rata-rata dan penentuan tipe pasut, pembuatan peta pesebaran pasut, dan pembuatan web. Pengolahan data arus laut meliputi perhitungan detail (ekstrapolasi), pembuatan peta pola arus, dan pembuatan web. Perhitungan variasi tinggi muka air, perhitungan detail, dan penentuan tipe pasang surut dengan menggunakan software Microsoft Excel 2013, pembuatan peta persebaran pasang surut dan pola arus menggunakan software ArcGIS 10 dan QuantumGIS 2.8.1 (QGIS), dan pembuatan Web melalui software Adobe Dreamweaver CS6. Hasil akhir yang diperoleh berupa web pasang surut dan arus laut di Pulau Batam. 


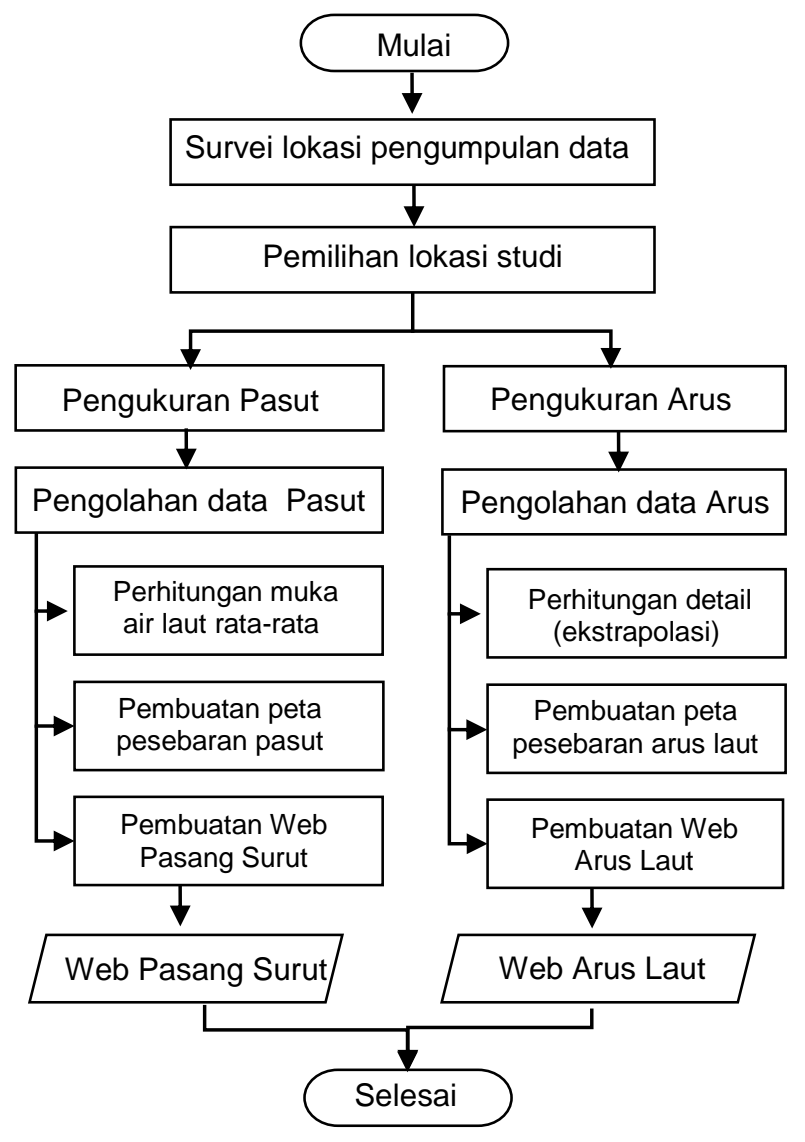

Gambar 2. Desain penelitian

Tahapan pengukuran pasang surut dilapangan dilakukan sesuai dengan SNI 7646 tahun 2010, yaitu: (1) mendirikan rambu ukur, perkirakan dengan teliti tempat berdirinya alat, dengan asumsi bahwa selama melakukan pengukuran posisi muka air tidak akan berada di bawah skala 0 (nol) atau di bawah rambu ukur. Pengambilan data pasang surut mulai dilakukan dengan awal waktu yang tepat, misal pukul $12.00 \mathrm{WIB}$, (2) melakukan pengambilan data pasang surut selanjutnya dilakukan setiap interval 30 menit, (3) merekam titik koordinat dengan menggunakan GPS, dan (4) masukan data hasil pengukuran dimasukkan ke dalam tabel pengamatan.

Tahapan pengukuran arus laut di lapangan (Basuki, 2006), yaitu: (1) perekaman koordinat, titik yang di rekam ada dua, pertama titik berdirinya theodolite dan kedua titik letaknya kompas. Pengambilan data arus laut dengan Theodolit, dengan terlebih dahulu memastikan alat berdiri dengan kondisi sempurna, menjauhi berbagai ganguan, dan alat sudah selesai diseting, (2) pengukuran jarak, menggunakan pita ukur bisa diketahui jarak titik Theodolite ke titik Kompas, peneliti memberi jarak pengukuran $5 \mathrm{~cm}$, hal ini untuk mempermudah mengetahui jarak yang ada di lapangan, yang harus sesuai dengan jarak dalam perhitungan, sehingga data yang di peroleh lebih detail, (3) bacaan horizontal, pengaturan bacaan horizontal Theodolite sebagai pengukuran harus diperhatikan dengan baik, dan melihat Nivo-nivo (kotak berisi air yang berfungsi mengetahui objek sudah rata secara vertikal dan horizontal) yang ada di Theodolit memperhatikan tata tempat terletaknya suatu alat, agar data yang diperoleh lebih detail, (4) pengamatan pergerakan target, theodolit dan kompas melakukan pengamatan bersamaan dengan membidik bola duga, bola duga dibiarkan bergerak sesuai dengan masa air yang ada di lokasi, bola di beri tali yang sepanjang $10 \mathrm{~cm} \mathrm{~s} / \mathrm{d} 15 \mathrm{~cm}$, sehingga bola lebih luas dalam mengikuti pergerakan masa air tersebut, dengan jarak interval 1 menit setiap pengamatan yang ada di lapangan, dan (5) pencatatan data, setelah melakukan pengamatan dengan theodolite dan kompas maka dapat nilai azimut dari theodolite dan kompas, maka nilai tersebut bisa di catat. Dalam pencatatan yang dibutuhkan adalah nilai bacaan horizontal dari theodolit dan nilai bacaan 
ISSN: 1907-9931 (print), 2476-9991 (online)

utara dari kompas, nilai yang di dapat dari theodolit dan kompas tidak terlalu jauh, karena samasama mengacu pada arah utara.

\section{HASIL DAN PEMBAHASAN}

\section{Analisis Pasang Surut Laut Pulau Batam}

Peta tipe pasang surut air laut di Pulau Batam dapat dilihat pada Gambar 3. Peta ini menampilkan grafik pasang surut pada masing-masing lokasi penelitian. Grafik pasang surut yang dihasilkan memiliki bentuk yang sama yaitu terdiri dari dua kali pasang tertinggi dan dua kali surut terendah di semua lokasi penelitian pasang surut yang berarti bahwa pasang surut di Pulau Batam bertipe semidiurnal atau pasang surut harian ganda.

Berdasarkan pengukuran pasang surut di Mega Wisata Ocarina pasang tertinggi pertama di tanggal 26 September 2015 pada pukul 09:00 dengan tinggi air $255 \mathrm{~cm}$, pasang tertinggi kedua di tanggal 26 September 2015 pada pukul 21:00 dengan tinggi air $271 \mathrm{~cm}$. Untuk surut terendah pertama terjadi pada pukul 02:00 di tanggal 26 September 2015 dengan tinggi air $49 \mathrm{~cm}$ dan surut terendah kedua pada pukul 15:30 pada tanggal 26 September 2015 dengan tinggi air 112 $\mathrm{cm}$. Nilai variasi tinggi muka air kawasan Mega Wisata Ocarina, Punggur, Nongsa, Tanjung Riau, dan Barelang disajikan pada Tabel 3.

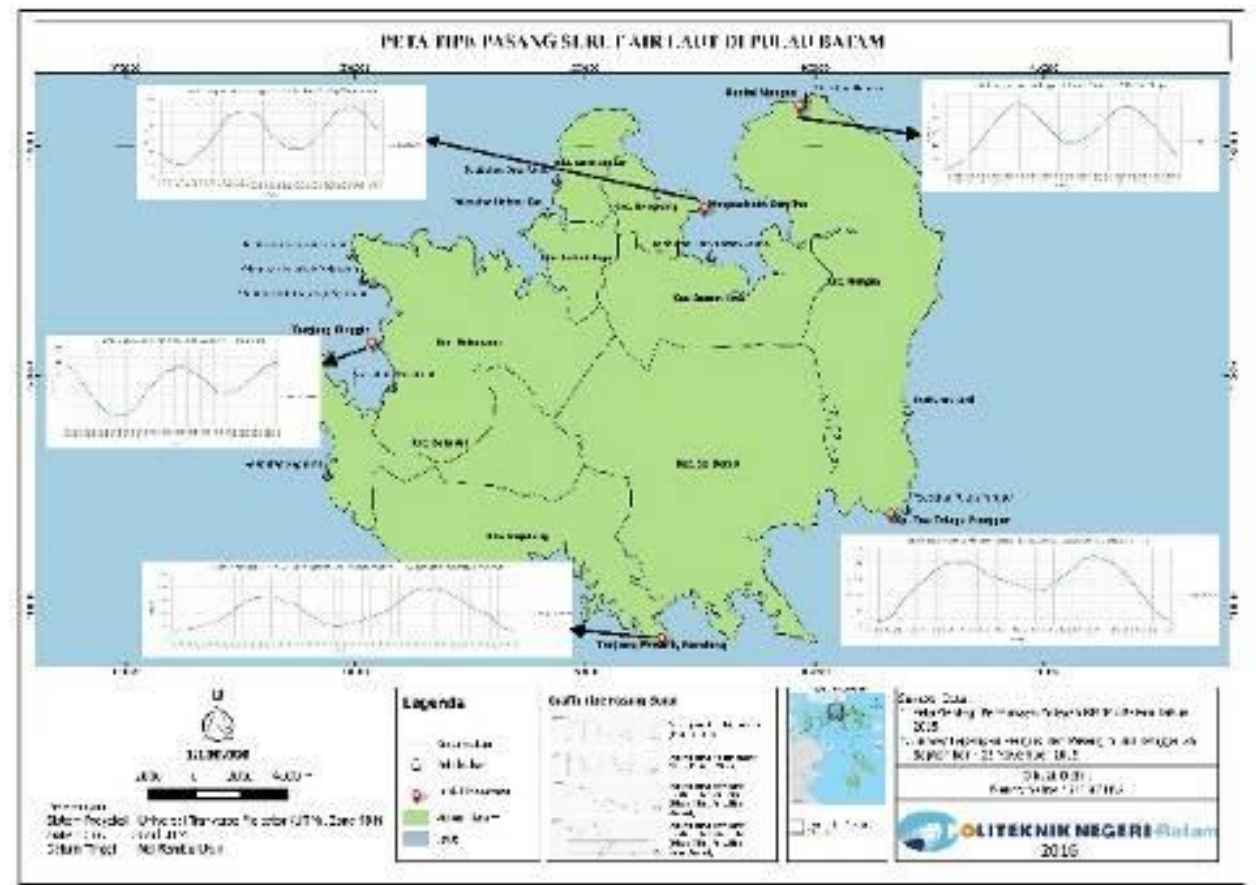

Gambar 3. Peta tipe arus laut Pulau Batam

Peta tipe pasang surut air laut di Pulau Batam dapat dilihat pada Gambar 3. Peta ini menampilkan grafik pasang surut pada masing-masing lokasi penelitian. Grafik pasang surut yang dihasilkan memiliki bentuk yang sama yaitu terdiri dari dua kali pasang tertinggi dan dua kali surut terendah di semua lokasi penelitian pasang surut yang berarti bahwa pasang surut di Pulau Batam bertipe semidiurnal atau pasang surut harian ganda. 
Volume 9, No. 1, April 2016

ISSN: 1907-9931 (print), 2476-9991 (online)

Tabel 3. Nilai variasi muka air di lokasi penelitian

\begin{tabular}{lrrrrr}
\hline \multirow{2}{*}{ Variasi } & \multicolumn{5}{c}{ Tinggi Muka Air (cm) } \\
\cline { 2 - 6 } & Ocarina & Punggur & Nongsa & $\begin{array}{c}\text { Tanjung } \\
\text { Riau }\end{array}$ & \multicolumn{1}{c}{ Barelang } \\
\hline HW & 271 & 224 & 262 & 248 & 197 \\
MHHWL & 245,735 & 201,964 & 236,729 & 225,781 & 174,592 \\
MHWL & 220,469 & 179,929 & 211,458 & 203,561 & 152,184 \\
MSL & 169,939 & 135,857 & 160,917 & 159,122 & 107,367 \\
MLWL & 109,469 & 72,929 & 87,458 & 99,561 & 69,184 \\
MLLWL & 79,235 & 41,464 & 50,729 & 69,781 & 50,092 \\
LW & 49 & 10 & 14 & 40 & 31 \\
Tide Range & 222 & 214 & 248 & 208 & 166 \\
\hline
\end{tabular}

Berdasarkan pengukuran pasang surut di Kampung Tua Telaga Punggur (Gambar 4) menunjukkan bahwa dalam satu hari terjadi dua kali pasang dan dua kali surut. Pasang tertinggi pertama terjadi pada pukul 01:30 dengan tinggi air $204 \mathrm{~cm}$, sedangkan pasang tertinggi kedua terjadi pada pukul 12:00 dengan tinggi air $224 \mathrm{~cm}$ di tanggal 31 Oktober 2015. Surut terendah pertama terjadi pukul 07:30 dengan tinggi air $110 \mathrm{~cm}$, dan surut terendah kedua terjadi pada pukul 18:00 dengan tinggi air $17 \mathrm{~cm}$ di tanggal 31 Oktober 2015.

Berdasarkan pengukuran pasut di Pantai Nongsa menunjukkan pasang tertinggi pertama terjadi pada pukul 01:30 dengan tinggi air $262 \mathrm{~cm}$, dan pasang tertinggi kedua terjadi pada pukul 12:30 dengan tinggi air $252 \mathrm{~cm}$ di tanggal 1 November 2015. Sedangkan surut terendah pertama terjadi pada pukul 06.30 dengan tinggi air $111 \mathrm{~cm}$, dan surut terendah kedua terjadi pada pukul 18:00 dengan tinggi air $51 \mathrm{~cm}$ di tanggal 1 November 2015.

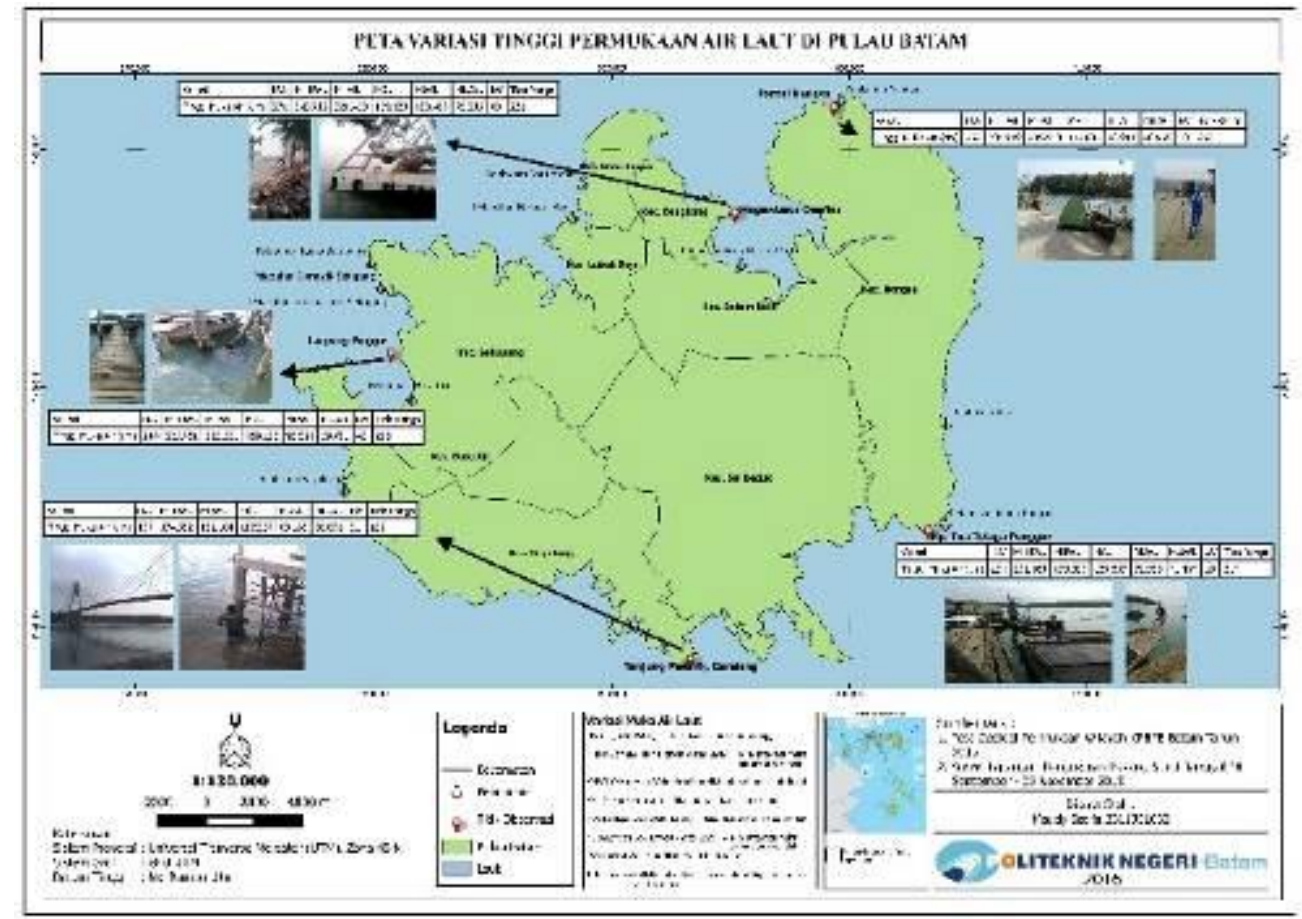

Gambar 4. Peta variasi muka air laut Pulau Batam

Berdasarkan pengukuran pasang surut di Kampung Tua Tanjung Riau pasang tertinggi pertama terjadi pada pukul 04:00 dengan tinggi air $234 \mathrm{~cm}$, dan pasang tertinggi kedua terjadi pada pukul 
ISSN: 1907-9931 (print), 2476-9991 (online)

14:30 dengan tinggi $248 \mathrm{~cm}$ di tanggal 19 November 2015. Untuk surut terendah pertama terjadi pada pukul 21:00 dengan tinggi air $40 \mathrm{~cm}$ di tanggal 18 November 2015, sedangkan surut terendah kedua terjadi pada pukul 09:00 dengan tinggi air $132 \mathrm{~cm}$ di tanggal 19 November 2015.

Berdasarkan pengukuran pasang surut di Tanjung Penarik, Jembatan 1 Barelang pasang tertinggi pertama terjadi pada pukul 22:30 dengan tinggi air $161 \mathrm{~cm}$ di tanggal 24 November 2015, dan pasang tertinggi kedua terjadi pada pukul 09:30 dengan tinggi air $197 \mathrm{~cm}$ di tanggal 25 November 2015. Untuk surut terendah pertama terjadi pada pukul 03:30 dengan tinggi air $48 \mathrm{~cm}$, dan surut terendah kedua terjadi pada pukul 16:00 dengan tinggi air $31 \mathrm{~cm}$ di tanggal 25 November 2015.

\section{Analisis Pola Arus Laut Pulau Batam}

Peta pola arus laut pulau Batam peta arus laut pulau Batam disajikan pada Gambar 5 analisis sebagai berikut:

- Pada laut kawasan Batam Center (Pantai Ocarina), arus paling kuat sekitar 0,06 m/s $(6 \mathrm{~cm} / \mathrm{s})$ ke arah timur laut, sedangkan arus paling lemah sekitar $0,04 \mathrm{~m} / \mathrm{s}$ ke arah timur laut.

- Pada laut kawasan Nongsa (Pantai Nongsa), arus paling kuat sekitar 0,1 m/s ke arah timur laut, sedangkan arus paling lemah sekitar $0,04 \mathrm{~m} / \mathrm{s}$ ke arah timur laut.

- Pada laut kawasan Sekupang, arus paling kuat sekitar 0,06 m/s ke arah utara sedangkan arus paling lemah sekitar $0,04 \mathrm{~m} / \mathrm{s}$ ke arah utara.

- Pada laut kawasan Punggur, arus paling kuat sekitar 0,06 m/s ke arah barat laut sedangkan arus paling lemah sekitar $0,02 \mathrm{~m} / \mathrm{s}$ ke arah barat laut.

- Pada laut kawasan Batu Ampar, arus paling kuat sekitar 0,1 m/s ke arah timur laut, sedangkan arus paling lemah sekitar $0,08 \mathrm{~m} / \mathrm{s}$ ke arah timur laut.

- Pada laut kawasan Jembatan Barelang, arus paling kuat sekitar 0,04 m/s ke arah timur laut, sedangkan arus paling lemah sekitar $0,02 \mathrm{~m} / \mathrm{s}$ ke arah timur laut.

Jadi, secara umum besar arus laut pada pulau batam berkisar antara $0,02 \mathrm{~m} / \mathrm{s}$ sampai $0,01 \mathrm{~m} / \mathrm{s}$ ke arah timur laut.
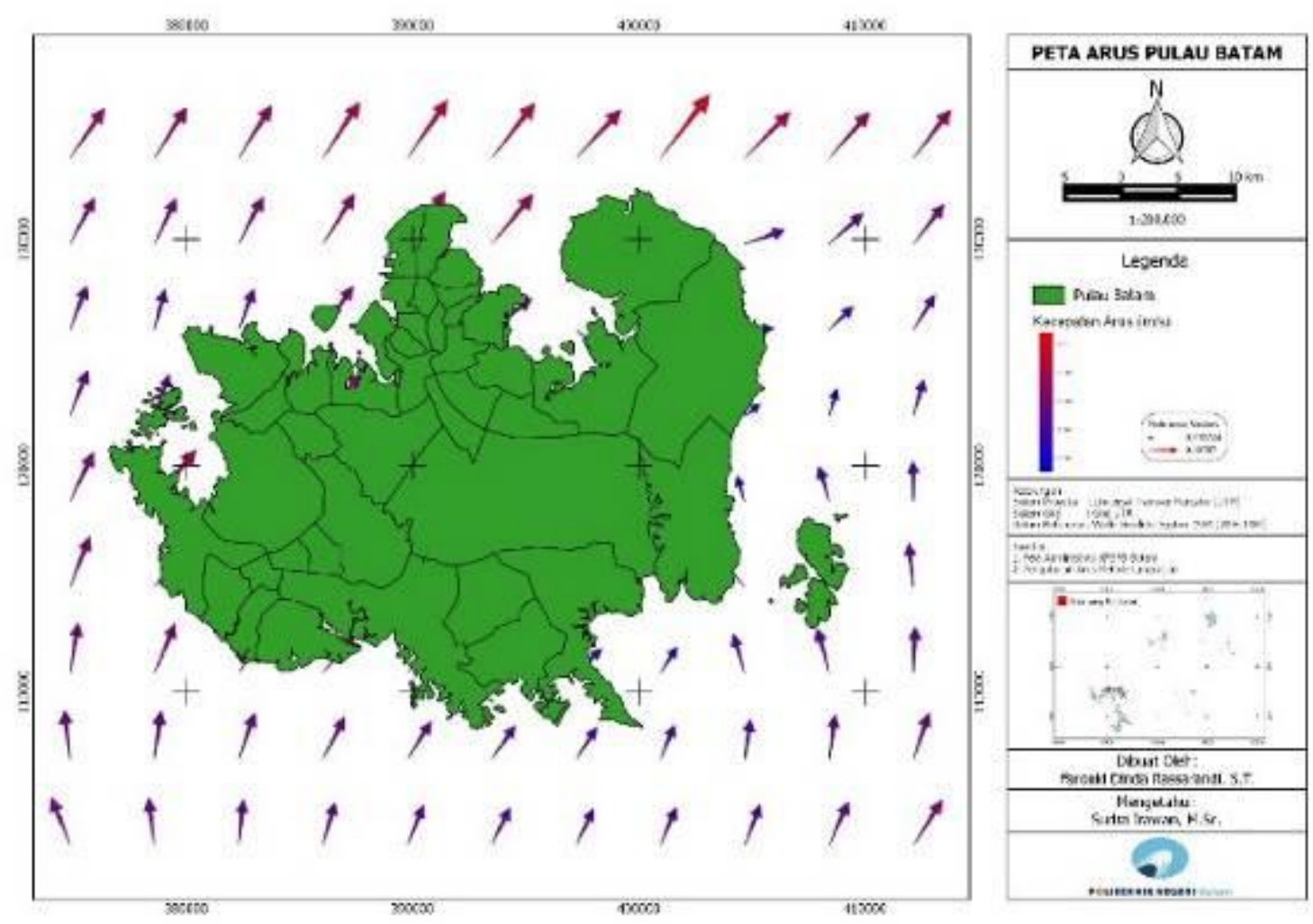

Gambar 5. Peta pola arus laut Pulau Batam 


\section{Hubungan Pasang Surut Terhadap Jalur Transportasi Antarpulau}

Sebagai wilayah kepulauan, Kota Batam sangat bergantung dengan pelabuhan laut dalam menunjang berbagai aktivitas kegiatan penduduknya. Hal ini karena sebagian besar wilayah Kota Batam terdiri dari pulau-pulau yang jumlahnya 356 pulau. Saat ini sarana perhubungan laut telah tersedia 14 (empat belas) pelabuhan yaitu lima pelabuhan penumpang internasional dengan tujuan Singapura dan Malaysia, dua pelabuhan domestik, satu pelabuhan PELNI, tiga pelabuhan rakyat dan tiga pelabuhan angkutan barang baik untuk tujuan domestik maupun internasional dengan kapasitas sandar kapal maksimum 35.000 DWT. Transportasi laut merupakan transportasi utama yang banyak digunakan oleh masyarakat Kota Batam. Modal yang umumnya digunakan adalah berupa kapal fery, pompong, pancung, dan speed boat (Batam dalam Angka, 2014).

Kawasan pelabuhan laut di Kota Batam selain berfungsi sebagai sarana transportasi laut, juga difungsikan sebagai pusat alih kapal guna memanfaatkan peluang adanya potensi limpahan dari Singapura serta untuk meningkatkan usaha perdagangan dan melancarkan arus bongkar muat barang dalam menunjang kegiatan industri. Fungsi ini kemudian diperluas sebagai tempat penyimpanan dan pergudangan bagi produk ekspor dan impor. Kunjungan kapal di pelabuhan merupakan salah satu indikator yang menggambarkan tingkat kesibukan aktivitas suatu pelabuhan. Dalam hal ini sarana angkutan laut merupakan alternatif lain di luar angkutan udara yang sangat berpotensi sesuai dengan kondisi geografis Kota Batam. Untuk melayani masuknya kunjungan wisatawan mancanegara ke Kota Batam telah tersedia fasilitas pelabuhan laut internasional dengan menggunakan ferry cepat yang berlayar setiap hari dari dan ke Singapura dan Malaysia.

Pesatnya perkembangan kota Batam ditandai dengan pembangunan pelabuhan-pelabuhan baru dan pembuatan rute perjalanan antarpulau memerlukan data hidrooseanografi, yang meliputi batimetri (kedalaman), pasang surut, besar dan arah arus, serta topografi bawah laut. Penentuan tipe pasang surut dan pola arus merupakan salah satu faktor penting yang harus diukur atau dilakukan pengamatan berdasarkan lokasi dan periode waktu tertentu.

Suatu bangunan pelabuhan yang digunakan untuk merapat dan menambatkan kapal yang melakukan bongkar muat barang dan menaik turunkan penumpang. Dasar pertimbangan dalam perencanaan dermaga yaitu salah satunya adalah elevasi dermaga ditentukan dengan memperhatikan kondisi elevasi muka air pasang (Gambar 6)
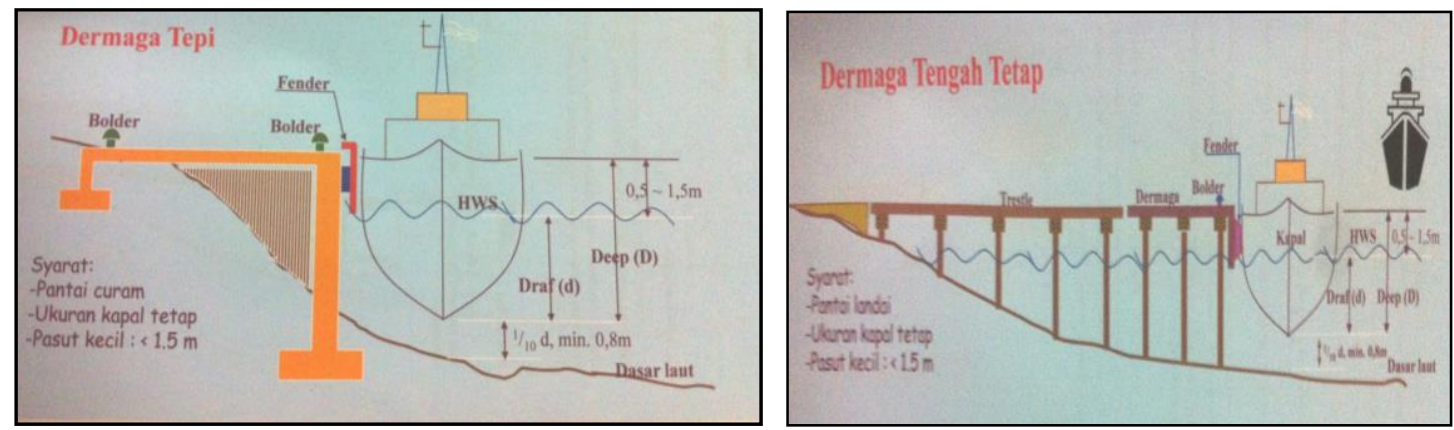

Gambar 6. Dermaga tepi dan dermaga tengah tetap (Triatmodjo, 2003)

Pasang surut juga digunakan dalam penentuan jalur pelayaran. Alur pelayaran berfungsi untuk mengarahkan kapal yang akan masuk ke kolam pelabuhan. Alur pelayaran dan kolam pelabuhan harus cukup tenang terhadap pengaruh gelombang dan arus. Kedalaman alur pelayaran ditentukan oleh muka air surut (Gambar 7). Survei pelayaran berguna karena kapal yang berlayar dipengaruhi oleh faktor-faktor alam seperti angin, gelombang, dan arus yang dapat menimbulkan gaya-gaya yang bekerja pada badan kapal. Faktor tersebut semakin besar apabila pelabuhan terletak di pantai yang terbuka ke laut dan begitupun juga sebaliknya (Diposaptono, 2007). 


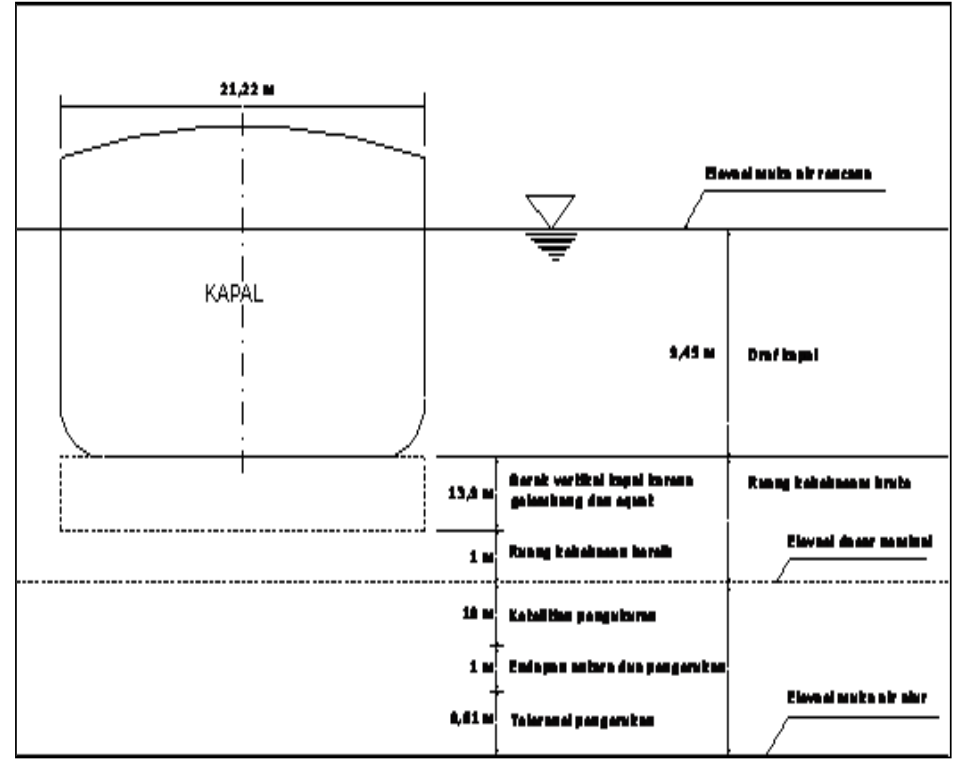

Gambar 7. Muka air laut surut untuk jalur pelayaran (Triatmodjo, 2003)

Survei pasang surut berguna untuk pelayaran karena kapal-kapal memerlukan kedalaman air yang sama dengan syarat (draft) kapal ditambah dengan suatu kedalaman tambah. Kedalaman air untuk pelabuhan didasarkan pada frekuensi kapal-kapal dengan ukuran tertentu yang masuk ke pelabuhan. Jika kapal-kapal terbesar masuk ke pelabuhan hanya satu kali dalam beberapa hari, maka kapal tersebut hanya boleh masuk pada waktu air pasang sedangkan kapal-kapal kecil harus dapat masuk ke pelabuhan pada setiap saat. Gelombang menimbulkan gaya-gaya yang bekerja pada kapal dan bangunan pelabuhan. Untuk itu perlu survei arah dan tinggi gelombang menuju pantai, arah dan kecepaatan arus untuk menghindari gangguan gelombang tersebut.

Pada perancangan kolam pelabuhan, pasang surut digunakan ketika kegiatan bongkar muat barang, pengisian ulang bahan bakar dan air bersih. Parameter yang digunakan dalam penentuan perencanaan kolam pelabuhan adalah elevasi muka air laut rencana berdasarkan muka air surut (Gambar 8).

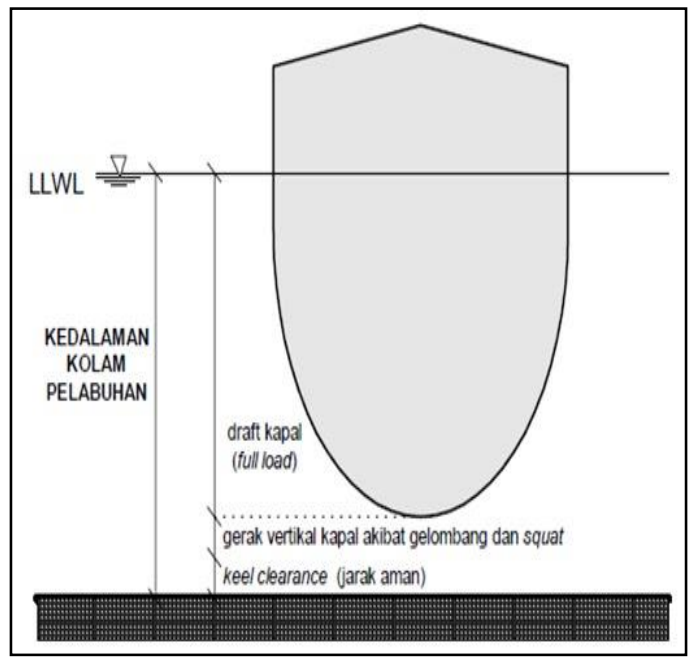

Gambar 8. Kedalam kolam pelabuhan (Triatmodjo, 2003) 
Perencanaan pemecah gelombang (Break Water) juga memerlukan informasi pasang surut dan arus laut sekitarnya. Pemecah gelombang adalah salah satu bangunan pantai yang berfungsi memecah energi gelombang dengan maksud untuk melindungi pantai, kolam pelabuhan, dan fasilitas pelabuhan lain dari gangguan gelombang yang dapat mempengaruhi keamanan dan kelancaran aktivitas di pelabuhan. Dimensi tinggi dan tebal Pemecah Gelombang / Break Water ditentukan oleh elevasi muka air pasang (Gambar 9).

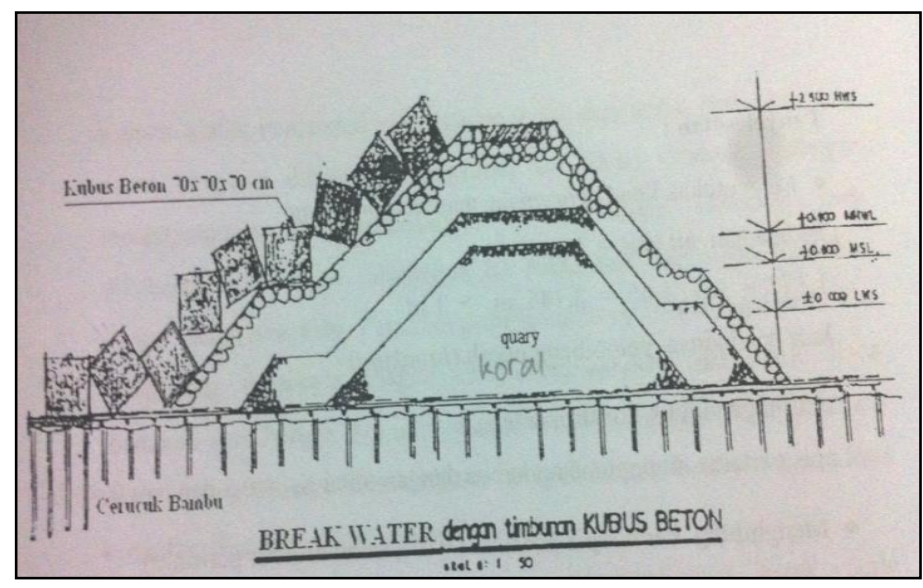

Gambar 9. Break water kubus beton (Triatmodjo, 2003)

\section{KESIMPULAN DAN SARAN}

Berdasarkan penelitian yang telah dilakukan, dapat disimpulkan:

1. Tipe pasang surut Pulau Batam secara umum adalah pasang surut harian ganda (semi diurnal tide), artinya dalam sehari terjadi dua kali pasang dan dua kali surut secara berurutan. Periode pasang surut rata-rata 12 jam 24 menit. Tinggi gelombang sekitar 0,2 sampai 2,77 meter dari arah selatan ke arah barat laut. Peta pasang surut dapat ditampilkan dalam bentuk web;

2. Pola arus laut Pulau Batam berkisar antara $0,02 \mathrm{~m} / \mathrm{s}$ sampai $0,01 \mathrm{~m} / \mathrm{s}$ dari arah utara ke arah timur laut.

3. Penentuan tipe pasang surut dan arus laut merupakan salah satu syarat penting dalam pengembangan transportasi antarpulau, meliputi perancangan bangunan pelabuhan, penentuan rute transportasi, perancangan kolam pelabuhan, dan perencanaan pemecah gelombang.

\section{UCAPAN TERIMA KASIH}

Penulis mengucapkan terima kasih kepada Politeknik Negeri Batam yang menyediakan peralatan untuk alat pengumpulan data dan reviewer yang telah memberikan masukan untuk penyempurnaan tulisan ini.

\section{DAFTAR PUSTAKA}

Atmodjo, W. (2011). Studi penyebaran sedimen tersuspensi di muara Sungai Porong Kabupaten Pasuruan. Buletin Oseanografi Marina, 1(1), 60-81.

Basuki, S. (2006). Ilmu ukur tanah. Yogyakarta: Gadjah Mada University Press.

Coremap Kota Batam (2007). Penetapan lokasi marine management area Coremap Kota Batam, SK Walikota Batam No. KPTS.114/HK/VI/2007.

Diposaptono, S. (2007). Karakteristik laut pada kota pantai. Direktorat Bina Pesisir, Direktorat Jendral Urusan Pesisir dan Pulau-pulau Kecil. Jakarta: Departemen Kelautan dan Perikanan. Jakarta.

Pemerintah Kota Batam (2014). Batam dalam Angka. Batam. Bapedda Kota Batam. 
SNI 7646 (2010). Survei hidrografi menggunakan single beam echosounder. Jakarta: Badan Standarisasi Nasional.

Sudjana (2005). Metoda statistika. Jakarta: Tarsito.

Sutirto \& Diarto (2014). Gelombang dan arus laut lepas. Kupang: Graha IImu.

Triatmodjo, B. (2003). Pelabuhan. Yogyakarta: Beta Offset. 